\title{
Analysis of chemical compounds' content in different varieties of carrots, including qualification and quantification of sugars, organic acids, minerals, and bioactive compounds by UPLC
}

\author{
Emel Yusuf ${ }^{1} \cdot$ Karolina Tkacz $^{1} \cdot$ Igor Piotr Turkiewicz $^{1} \cdot$ Aneta Wojdyło $^{1} \cdot$ Paulina Nowicka $^{1}$ (D)
}

Received: 1 July 2021 / Revised: 26 August 2021 / Accepted: 27 August 2021 / Published online: 10 September 2021

(c) The Author(s) 2021

\begin{abstract}
Twelve carrot varieties in different colours and sizes were investigated for chemical properties (dry matter, ash, pectins, titratable acidity, and $\mathrm{pH}$ ), contents of vitamin $\mathrm{C}$, sugar, organic acids, mineral (sodium, potassium, calcium, iron, and magnesium), and anti-oxidant activities (ABTS, FRAP, and ORAC). Moreover, total polyphenolics and total tetraterpenoids of colourful carrot varieties were presented. According to the study, sucrose was the dominant sugar and isocitric acid was the most common organic acid in carrot samples. In the case of mineral content, potassium, sodium, calcium, magnesium, and iron were identified, while copper was not identified in carrots. Additionally, most of the analyzed carrots were a good source of pectins (average-1.3\%), except for mini-orange carrot. Purple-coloured carrot samples demonstrated the highest results for total sugar $(11.2 \mathrm{~g} / 100 \mathrm{~g} \mathrm{fm})$, total organic acid $(2.8 \mathrm{~g} / 100 \mathrm{~g} \mathrm{fm})$, total polyphenolic contents $(224.4 \mathrm{mg} / 100 \mathrm{~g} \mathrm{fm})$, and anti-oxidant activities ( $17.1 \mathrm{mmol}$ Trolox equivalents/100 $\mathrm{g} \mathrm{dm}$ ). In turn, the lowest results were observed in normal yellow carrot for total polyphenols $(7.3 \mathrm{mg} / 100 \mathrm{~g} \mathrm{fm})$, and anti-oxidant activities ( $2.5 \mathrm{mmol}$ Trolox equivalents $/ 100 \mathrm{~g} \mathrm{dm})$; besides, the lowest total tetraterpenoids were determined in micro-white carrot $-0.2 \mathrm{mg} / 100 \mathrm{~g} \mathrm{fm}$.
\end{abstract}

Keywords Carrot roots · Chemical properties · Polyphenolic compounds · Carotenoids · Antioxidant activity

\section{Introduction}

Global dietary guidelines support boosting fruit and vegetables consumption and recommend five portions of fruit and vegetables per day [1]. It results from the fact that fruit and vegetables consumption prevent non-communicable diseases such as cardiovascular disorders, obesity, diabetes, and cancer [2]. However, many people do not consume fruit and vegetables for varied reasons such as price, eating habits, time, and concerns about fruit and vegetables production [3]. Thus, poor diet is the one reason to cause $80 \%$ of death from non-communicable diseases [4].

Childhood is a period when people can gain healthy eating habits from their parents [5]. Parental nutritional knowledge increases the consumption of more fruit, vegetables,

Paulina Nowicka

paulina.nowicka@upwr.edu.pl

1 Department of Fruit, Vegetable and Nutraceutical Plant Technology, Wrocław University of Environmental and Life Sciences, 37 Chełmońkiego Street, 51-630 Wrocław, Poland and fiber intakes of children [6]. Besides, the food choices of parents influence the eating habits of children as well [7]. For instance, to increase the fruit and vegetables consumption of children, parents may purchase more colourful fruit and vegetables. Moreover, family members can consume these raw materials together to gain more healthy eating habits. Hence, rainbow-healthy raw foods promote people to enhance their diet [8].

To clarify, colourful carrot varieties may apply with their elevated health benefits. Carrot breeding provides purple, orange, red, yellow, and white colours [9]. Besides, the chemical contents of carrots change depending on colours; carotenoids create orange and yellow colours [10,11], purple colour is the result of anthocyanins [12], and white carrot contains no colour pigments [13]. Except for colour features, bioactive compounds of carrots are precious with activities against diabetes, cardiovascular diseases, obesity, cancers, and aging $[14,15]$.

Like other fruit and vegetables, nutrients in carrots change with genes, environmental factors, fertilizer, and storage periods [16]. Carrot roots are rich in different carotenoid types as well as polyphenols [17]. However, carrot 
varieties are not restricted to those compounds. Hence, carrots are valuable with vitamin and mineral contents as well.

The mineral content determines product quality which is an important parameter for raw food products [18]. Carrot roots are abundant in potassium $(\mathrm{K})$, manganese $(\mathrm{Mn})$, phosphorus $(\mathrm{P})$, calcium $(\mathrm{Ca})$, sodium $(\mathrm{Na})$, iron $(\mathrm{Fe})$, and magnesium $(\mathrm{Mg})[19,20]$. These elements are essential minerals for human healthy body functions. Proof of these, $\mathrm{K}$ is necessary for functions of muscles, nerves, and cells; $\mathrm{Mn}$ is required in trace amounts for biosynthetic pathways; $\mathrm{P}$ shows functions for blood vessels and bones; $\mathrm{Ca}$ is essential for bones, teeth and blood cells; $\mathrm{Na}$ is necessary for functions of muscles and nerves; $\mathrm{Fe}$ is important for oxygen transportation in blood and muscle cells; besides, $\mathrm{Mg}$ adjusts blood sugar levels and blood pressure [21].

Vitamins in carrot varieties are another important content for product quality. Moreover, the main vitamin types in carrot varieties are the results of carotenoids. For instance, $\beta$-carotene is converted to vitamin A which is important against night blindness and increases immune system functions [22]. Second, $\alpha$-tocopherol is the precursor of vitamin E that is crucial for cell signalling, gene expression, and cell membrane stabilities in the human body [23]. Except for these two vitamins, carrots are abundant with vitamin C which is necessary for controlling blood pressure, preventing iron deficiency and boosting immune system functions [20, 24]. Moreover, vitamin B derivatives (thiamine, riboflavin, cobalamin, and pyridoxine) are rich in carrot varieties as well [25]; and vitamin B is important for the functions of cell growth, brain, and digestion system.

Besides, carrots are good sources of carbohydrates such as simple sugars like fructose, glucose, and sucrose, a small amount of starch and fibers [26]. Sugar contents and quantities of carrot varieties may change with the impact of environmental and storage conditions [27]. Dietary fibers, which provide healthy bowel function, decreasing cholesterol level, and heart diseases, are grouped as soluble and insoluble. For instance, pectin and hemicellulose are soluble; cellulose is insoluble fiber [28]. Moreover, mono-, di-, or oligo-saccharides of fruit and vegetables are categorized as prebiotics by CODEX Alimentarius [29].

On the other hand, fruit and vegetables are rich in organic acids. The most known acid of raw materials is ascorbic acid (vitamin C) with its high anti-oxidant activities. However, many others boost healthy body functions, as well. For instance, benzoic acid demonstrates antibacterial activity; hydroxycinnamic acid is an anti-inflammatory agent; gallic acid fights with mutagenic factors. Moreover, acetic, succinic, citric, lactic, malic acids, and their salts help to iron absorption [30].

Therefore, the study aims to compare 12 coloured carrot varieties with their chemical properties (dry matter, ash, pectin, titratable acidity, and $\mathrm{pH}$ ), and anti-oxidant activities (ABTS, FRAP, and ORAC). Moreover, carrot varieties have been contrasted for total polyphenolic compounds, vitamin $\mathrm{C}$, and total tetraterpenoid contents. Additionally, sugar, mineral, and organic acid profiles of carrot varieties have been presented. The study is the first to evaluate the chemical contents and anti-oxidant activities of colourful carrot varieties together.

\section{Materials and methods}

\section{Chemicals}

Standards of sugars, organic acids, carotenoids, chlorophylls, and polyphenolics were purchased from extrasynthese (Lyon, France). Acetonitrile, methanol, and formic acid for analyses of ultra-performance liquid chromatography (UPLC; Gradient grade) and ascorbic acid were purchased from Merck (Darmstadt, Germany). The additional reagents were purchased from Sigma-Aldrich (Taufkirchen, Germany).

\section{Plant material and sample preparation}

Normal and mini-sized carrots were purchased from Fusion Gusto (Dąbrowa, Poland). Micro carrots were purchased from Cato Produce (Johannesburg, South Africa) in June 2020. Normal-sized carrots were between 20 and $45 \mathrm{~mm}$ and weights from 50 to $150 \mathrm{~g}$; mini-sized carrots were between 10 and $20 \mathrm{~mm}$ and weights from 8 to $50 \mathrm{~g}$; micro-sized carrots were smaller than $10 \mathrm{~mm}$ and weights were smaller than $8 \mathrm{~g}$.

The following varieties of carrot were investigated: micro-yellow carrot (MYC), mini-yellow carrot (MiYC), normal yellow carrot (NYC); micro-purple carrot (MPC), mini-purple carrot (MiPC), normal purple carrot (NPC); micro-orange carrot (MOC), mini-orange carrot (MiOC), normal orange carrot (NOC); micro-white carrot (MWC), mini-white carrot (MiWC), and normal-white carrot (NWC).

Approximately $2 \mathrm{~kg}$ of carrot roots were separated into two parts. One part of carrot varieties was analyzed for the contents of dry matter, ash, soluble solids, $\mathrm{pH}$, titratable acidity, pectin, L-ascorbic acid, sugars, and organic acids. The second part of carrot roots was washed, dried, cut into slices, and then frozen at $-80{ }^{\circ} \mathrm{C}$. The sliced carrots were then freeze-dried ( $24 \mathrm{~h}$; Christ Alpha 1-4 LSC, Melsungen, Germany) and crushed by a laboratory mill (IKA A 11, Staufen, Germany) to obtain the homogeneous dry material for analysis. 


\section{Physicochemical analyses}

Titratable acidity (TA) was evaluated by $0.1 \mathrm{~N} \mathrm{NaOH}$ to an endpoint of $\mathrm{pH} 8.1$ using an automatic $\mathrm{pH}$ titration system (pH-meter type IQ 150; Warsaw, Polska) and expressed as g malic acid/100 g FW (fresh weight). The $\mathrm{pH}$ of carrots was measured using the same equipment as that used for TA. The dry matter was estimated by mixing the sample with diatomaceous earth, pre-dried, and final drying under reduced pressure. The dry matter and TA were determined using the following PN norms: PN-EN 12,145:2001 and PN-EN 12,145:2000, respectively. Pectin content (mg/100 g FW) was evaluated according to Pijanowski et al. [31]. The contents of ash (\%), L-ascorbic acid (mg/100 g FW), sugars, and organic acids (g/100 g FW) were determined according to Wojdyło et al. [32]. The content of sugars was estimated by HPLC-ELSD (Merck, Hitachi, Japan). The content of organic acids in carrots was quantified by Ultra Performance Liquid Chromatography with Photodiode Array Detector (Acquity UPLC System, Waters Corp., Milford, MA, USA). Organic acids were identified using reference standards (Merck KGaA, Darmstadt, Germany). The content of minerals in carrots was determined using Atomic Absorption Spectrophotometers (AA-7000F/AAC SHIMADZU, Shimadzu Corporation). All measurements were performed in triplicate.

\section{Quantification of bioactive compounds}

The quantification (UPLC/PDA/FL-ACQUITY UPLC BEH C18 column $(1.7 \mu \mathrm{m}, 2.1 \times 100 \mathrm{~mm}$, Waters Corporation, Milford, USA) at $30{ }^{\circ} \mathrm{C}$. The injection and elution of the samples $(5 \mu \mathrm{L})$ were concluded in 15 min with a sequence of linear gradients and a flow rate of $0.42 \mathrm{~mL} /$ min. The solvent A ( $2.0 \%$ formic acid, $\mathrm{v} / \mathrm{v})$ and solvent B (100\% acetonitrile) comprised the mobile phase. The procedure operated through gradient elution with 99-65\% solvent A (0-12 min), solvent A was later lowered to $0 \%$ for condition column (12.5-13.5 $\mathrm{min})$, and the gradient returned to the initial composition (99\% A) for $15 \mathrm{~min}$ to re-equilibrate the column) of polyphenolics was performed according to Wojdyło et al. [33]. The polyphenols' quantification was performed by external calibration curves and reference standards.

The quantifications (UPLC-PDA) of tetraterpenoids were performed according to Wojdyło et al. [34] by retention times and spectra to compare with authentic standards. The determination of tetraterpenoids was performed according to Kolniak-Ostek [35]. The total values of polyphenols and carotenoids were given as fresh weights (FW) after the identification and quantification of each bioactive compound. The results are expressed as $\mathrm{mg} / 100 \mathrm{~g} \mathrm{FW}$.

\section{Determination of anti-oxidant activity of carrot varieties}

The ORAC (oxygen radical absorbance capacity), ABTS + (2,2'-azino-bis(3-ethylbenzothiazoline-6-sulphonic acid)), and FRAP (the ferric reducing ability of plasma) antioxidant activity assays were performed as described, respectively [36-38]. The results of anti-oxidant activity tests are shown as mmol of Trolox equivalents (TE) per $100 \mathrm{~g}$ of dry matter $(\mathrm{dm})$. All tests were performed in triplicate using a microplate reader SynergyTM H1 (BioTek, Winooski, VT, USA).

\section{Statistical analysis}

The two-way analysis of variance (ANOVA, $p \leq 0.05$ ) and Duncan's test were performed by Statistica version 13.3 (Stat-Soft, Cracow, Poland). The results are shown as the mean value $(n=3) \pm$ standard deviation $(\mathrm{SD})$.

\section{Results and discussion}

\section{Quantification of bioactive compounds in different varieties of carrot}

The total L-ascorbic acid, total polyphenolic, and total tetraterpenoid contents of carrot roots are shown in Fig. 1.

Humans cannot synthesise L-ascorbic acid and should obtain the vitamin from other sources such as fruits and vegetables [39]. Besides, the recommended daily intake of ascorbic acid is $75 \mathrm{mg}$ /day for an adult woman and $90 \mathrm{mg} /$ day for an adult man [40]. In the present study, the content of L-ascorbic acid ranged from 1.0 to $5.3 \mathrm{mg} / 100 \mathrm{~g}$ FW. The highest values were observed for MYC $(5.3 \pm 0.0$ a mg/100 g FW), followed by MPC $(5.0 \pm 0.0 \mathrm{~b} \mathrm{mg} / 100 \mathrm{~g}$ $\mathrm{FW})$ and MOC $(3.6 \pm 0.0 \mathrm{c} \mathrm{mg} / 100 \mathrm{~g} \mathrm{FW})$. Conversely, the lowest results were detected for NYC $(1.2 \pm 0.41 \mathrm{mg} / 100 \mathrm{~g}$ $\mathrm{FW})$ and NWC $(1.0 \pm 0.1 \mathrm{~m} \mathrm{mg} / 100 \mathrm{~g} \mathrm{FW})$. According to Alasalvar et al. [26], white carrot $(1.3 \mathrm{mg} / 100 \mathrm{~g} \mathrm{FW})$ had the lowest ascorbic acid content, while orange carrot $(5.3 \mathrm{mg} / 100 \mathrm{~g} \mathrm{FW})$ showed the highest amount of L-ascorbic acid. However, the authors could not quantify the ascorbic acid content in the purple carrot. In the present study, darkcoloured carrot samples exhibited much higher L-ascorbic acid content than other carrots, and similar results have been reported in the literature [41]. Moreover, micro- and minisized carrot samples showed better results for $\mathrm{L}$-ascorbic acid content than normal-sized carrot samples. In another study [42], the contents of L-ascorbic acid of six carrot varieties were compared during the storage periods. The result of the study demonstrated that after harvesting, L-ascorbic acid levels of carrot roots ranged from 54 to $132 \mathrm{mg} \mathrm{kg}^{-1}$. However, 


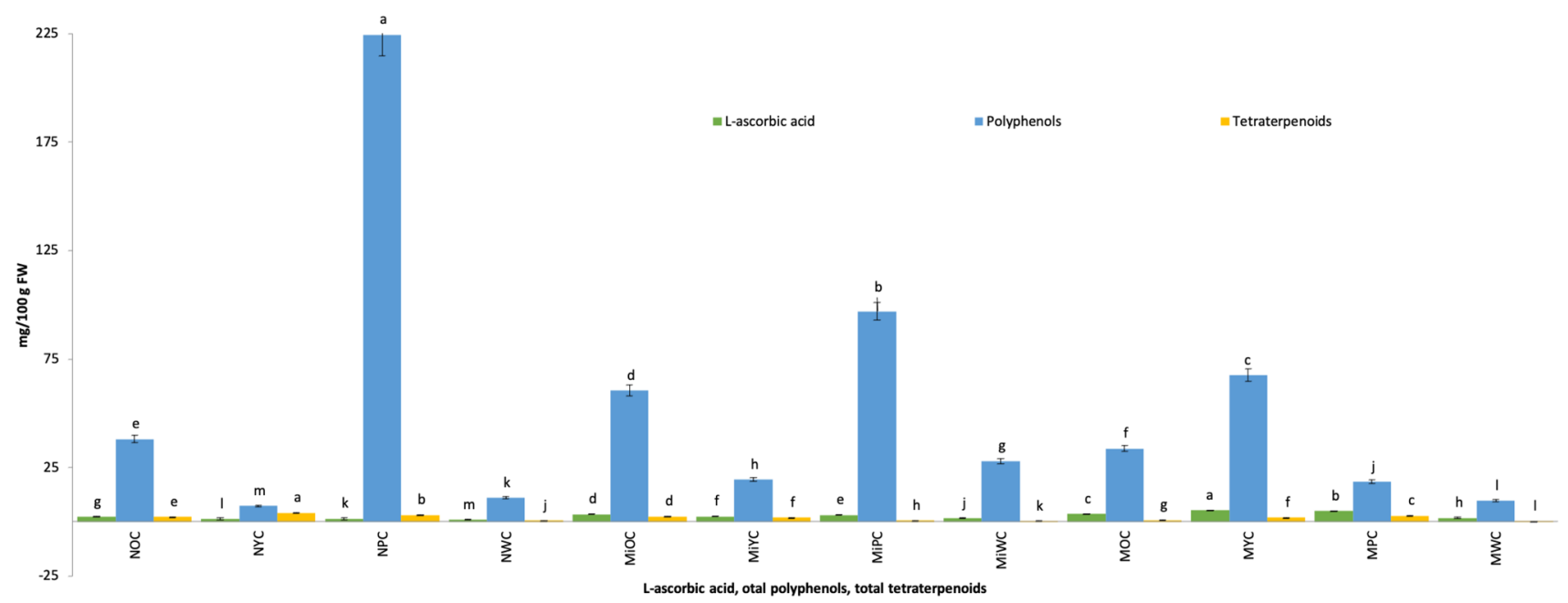

Fig. 1 Total L-ascorbic acid, total polyphenol, and total tetraterpenoid contents in colourful carrot varieties. The L-ascorbic acid, total polyphenol, and total tetraterpenoid contents $(\mathrm{mg} / 100 \mathrm{~g} \mathrm{FW})$ in 12 carrot varieties; significant at $p \leq 0.05$; $\ddagger$ values (mean of three replications) followed by the same letter were not significantly different $(p>0.05)$ according to Duncan's test after 30 days of storage, L-ascorbic acid levels decreased by almost $50 \%$. Therefore, the content of L-ascorbic acid changes depending on variety, carbon dioxide, temperature, storage, and age [43].

The total phenolic contents of carrot roots ranged from to $224.4 \mathrm{mg} / 100 \mathrm{~g} \mathrm{FW}$. The NPC $(224.4 \pm 9.5 \mathrm{a}$ $\mathrm{mg} / 100 \mathrm{~g} \mathrm{FW})$ and MiPC $(97.0 \pm 4.1 \mathrm{~b} \mathrm{mg} / 100 \mathrm{~g} \mathrm{FW}) \mathrm{had}$ the highest total polyphenolic contents. However, NYC $(7.3 \pm 0.3 \mathrm{~m} \mathrm{mg} / 100 \mathrm{~g} \mathrm{FW})$ and MWC $(9.8 \pm 0.41 \mathrm{mg} / 100 \mathrm{~g}$ FW) demonstrated the lowest contents of total phenolics. In the literature, the total phenolic content of beetroot is $257.2 \mathrm{mg} / 100 \mathrm{~g} \mathrm{FW}$, turnip $127.0 \mathrm{mg} / 100 \mathrm{~g} \mathrm{FW}$, and yam is $92.0 \mathrm{mg} / 100 \mathrm{~g} \mathrm{FW}[44,45]$. High total phenolic contents of plants are related to antimicrobial and anti-oxidant activities of species, as well $[46,47]$. Moreover, some phenolics activate anti-oxidant molecules in the cell [48]. Furthermore, phenolics are a part of chemicals that fight against diabetesrelated diseases [49]. Thus, the activities of phenolics can be influenced by many factors such as plant species, varieties, climate, storage conditions, and biotic and abiotic stress factors [50].

On the other hand, carotenoids and chlorophylls are a part of tetraterpenoids and support healthy body functions against aging, cataract, and cancer [51, 52]. In the present study, total tetraterpenoids of 12 carrot varieties ranged from 0.2 to $4.1 \mathrm{mg} / 100 \mathrm{~g} \mathrm{FW}$. The highest tetraterpenoid contents were observed in NYC $(4.1 \pm 0.2 \mathrm{a} \mathrm{mg} / 100 \mathrm{~g} \mathrm{FW})$ and NPC $(3.1 \pm 0.1 \mathrm{~b} \mathrm{mg} / 100 \mathrm{~g} \mathrm{FW})$; but the lowest tetraterpenoid contents were determined in MWC $(0.2 \pm 0.01 \mathrm{mg} / 100 \mathrm{~g}$ $\mathrm{FW})$ and MiWC $(0.4 \pm 0.0 \mathrm{k} \mathrm{mg} / 100 \mathrm{~g} \mathrm{FW})$. Normalsized and purple carrots were rich with total tetraterpenoid contents. In the literature, sweet potato and potato had $2.4 \mathrm{mg} / 100 \mathrm{~g}$ and $0.0 \mathrm{mg} / 100 \mathrm{~g}$ of total tetraterpenoid contents, respectively [53]. Therefore, tetraterpenoid contents can be affected for varied reasons such as plant types, harvesting conditions, climate, and soil factors of plants [54, 55]. Moreover, tetraterpenoid contents are closely related to the colours of plant parts or vice versa.

To summarise, when L-ascorbic acid, total polyphenolic, and total tetraterpenoid contents were evaluated together, any correlation was not found. However, MYC had the highest L-ascorbic acid content with the third place of the highest total polyphenols (after the NPC and MiPC). Besides, NPC had the highest total polyphenolics and the second-highest value of tetraterpenoids, as well.

\section{Sugar and organic acid profile of different carrot varieties}

Sugars and organic acids are crucial for the quality and sensory attractiveness of raw materials [56]. These natural compounds comprise approximately $60 \%$ of dry matter, soluble solid content, and flavour of fruits and vegetables [57]. In the present study, sugars and organic acids were found to provide the taste and sweetness to the carrot varieties. As shown in Table 1, significant differences $(p \leq 0.05)$ in sugar and organic acid contents were observed in carrot roots. Fructose, sorbitol, glucose, and sucrose were determined as sugar components in the studied carrot varieties. Fructose and glucose were observed in all carrot samples; however, sorbitol was detected only in NOC, MiOC, MiYC, MiPC, MOC, MYC, and MPC. Moreover, sucrose was not identified in MiPC. The highest fructose levels were observed in NOC (3.8 g/100 g FW), MWC (1.9 g/100 g FW), and MiYC $(1.9 \mathrm{~g} / 100 \mathrm{~g} \mathrm{FW})$; the highest sorbitol levels were found in MiYC (0.5 g/100 g FW) and MYC (0.4 g/100 g FW); the 
Table 1 Sugar and organic acid contents of carrot varieties

\begin{tabular}{|c|c|c|c|c|c|c|c|c|c|c|c|c|}
\hline Compounds & NOC & NYC & NPC & NWC & $\mathrm{MiOC}$ & MiYC & MiPC & MiWC & MOC & MYC & MPC & MWC \\
\hline Fructose & $3.78 * \mathrm{a}$ & $0.25^{\mathrm{g}}$ & $0.64^{\mathrm{f}}$ & $1.42^{\mathrm{c}}$ & $1.21^{\mathrm{d}}$ & $1.85^{\mathrm{b}}$ & $1.40^{\mathrm{c}}$ & $0.80^{\mathrm{e}}$ & $1.20^{\mathrm{d}}$ & $0.65^{\mathrm{f}}$ & $0.79^{\mathrm{e}}$ & $1.86^{\mathrm{b}}$ \\
\hline Sorbitol & $0.01^{\mathrm{f}}$ & $0.00^{\mathrm{f}}$ & $0.00^{\mathrm{f}}$ & $0.00^{\mathrm{f}}$ & $0.23^{\mathrm{c}}$ & $0.53^{\mathrm{a}}$ & $0.23^{\mathrm{c}}$ & $0.00^{\mathrm{f}}$ & $0.10^{\mathrm{e}}$ & $0.39^{\mathrm{b}}$ & $0.18^{\mathrm{d}}$ & $0.00^{f}$ \\
\hline Glucose & $1.31^{\mathrm{h}}$ & $0.79^{\mathrm{m}}$ & $0.91^{1}$ & $4.09^{\mathrm{a}}$ & $1.65^{\mathrm{f}}$ & $2.81^{\mathrm{c}}$ & $3.83^{\mathrm{b}}$ & $1.10^{\mathrm{j}}$ & $1.80^{\mathrm{e}}$ & $1.91^{\mathrm{d}}$ & $0.95^{\mathrm{k}}$ & $1.45^{\mathrm{g}}$ \\
\hline Sucrose & $0.53^{\mathrm{g}}$ & $4.56^{\mathrm{c}}$ & $9.68^{\mathrm{a}}$ & $1.57^{\mathrm{d}}$ & $0.40^{\mathrm{h}}$ & $0.31^{\mathrm{j}}$ & $0.00^{\mathrm{k}}$ & $7.45^{\mathrm{b}}$ & $0.56^{\mathrm{f}}$ & $0.84^{\mathrm{e}}$ & $0.82^{\mathrm{e}}$ & $0.81^{\mathrm{e}}$ \\
\hline Total sugars & $5.63^{\mathrm{d}}$ & $5.60^{\mathrm{d}}$ & $11.24^{\mathrm{a}}$ & $7.09^{c}$ & $3.49^{\mathrm{k}}$ & $5.50^{\mathrm{e}}$ & $5.46^{\mathrm{f}}$ & $9.35^{\mathrm{b}}$ & $3.66^{\mathrm{j}}$ & $3.79^{\mathrm{h}}$ & $2.73^{1}$ & $4.11^{\mathrm{g}}$ \\
\hline Oxalic acid & $0.26^{\mathrm{f}}$ & $0.20^{\mathrm{k}}$ & $0.17^{1}$ & $0.23^{\mathrm{h}}$ & $0.22^{\mathrm{j}}$ & $0.52^{\mathrm{b}}$ & $0.26^{\mathrm{g}}$ & $0.22^{\mathrm{j}}$ & $0.44^{\mathrm{c}}$ & $0.58^{\mathrm{a}}$ & $0.32^{\mathrm{e}}$ & $0.43^{\mathrm{d}}$ \\
\hline Maleic acid & $0.00^{\mathrm{a}}$ & $0.00^{\mathrm{a}}$ & $0.00^{\mathrm{a}}$ & $0.00^{\mathrm{a}}$ & $0.00^{\mathrm{a}}$ & $0.00^{\mathrm{a}}$ & $0.00^{\mathrm{a}}$ & $0.00^{\mathrm{a}}$ & $0.00^{\mathrm{a}}$ & $0.01^{\mathrm{a}}$ & $0.01^{\mathrm{a}}$ & $0.00^{\mathrm{a}}$ \\
\hline Citric acid & $0.10^{\mathrm{d}}$ & $0.04^{\mathrm{f}}$ & $0.06^{\mathrm{e}}$ & $0.00^{\mathrm{g}}$ & $0.00^{\mathrm{g}}$ & $0.00^{\mathrm{g}}$ & $0.00^{\mathrm{g}}$ & $0.00^{\mathrm{g}}$ & $0.00^{\mathrm{g}}$ & $0.14^{\mathrm{a}}$ & $0.11^{\mathrm{c}}$ & $0.12^{\mathrm{b}}$ \\
\hline Isocitric acid & $0.63^{\mathrm{h}}$ & $0.70^{\mathrm{e}}$ & $0.68^{\mathrm{g}}$ & $0.48^{\mathrm{j}}$ & $0.30^{\mathrm{k}}$ & $0.49^{j}$ & $0.28^{1}$ & $1.78^{\mathrm{a}}$ & $0.70^{\mathrm{f}}$ & $1.14^{\mathrm{b}}$ & $0.89^{\mathrm{c}}$ & $0.78^{\mathrm{d}}$ \\
\hline Malic acid & $0.34^{\mathrm{k}}$ & $0.60^{g}$ & $0.86^{\mathrm{a}}$ & $0.67^{\mathrm{d}}$ & $0.52^{\mathrm{h}}$ & $0.69^{\mathrm{c}}$ & $0.66^{\mathrm{e}}$ & $0.22^{\mathrm{m}}$ & $0.64^{\mathrm{f}}$ & $0.50^{\mathrm{j}}$ & $0.70^{\mathrm{b}}$ & $0.26^{1}$ \\
\hline Lactic acid & $0.31^{\mathrm{b}}$ & $0.18^{\mathrm{f}}$ & $0.21^{\mathrm{e}}$ & $0.00^{\mathrm{g}}$ & $0.00^{\mathrm{g}}$ & $0.00^{\mathrm{g}}$ & $0.00^{\mathrm{g}}$ & $0.00^{\mathrm{g}}$ & $0.30^{\mathrm{d}}$ & $0.00^{\mathrm{g}}$ & $0.40^{\mathrm{a}}$ & $0.31^{\mathrm{c}}$ \\
\hline Fumaric acid & $0.00^{\mathrm{h}}$ & $0.06^{\mathrm{c}}$ & $0.02^{\mathrm{f}}$ & $0.02^{\mathrm{ef}}$ & $0.03^{\mathrm{d}}$ & $0.02^{\mathrm{e}}$ & $0.02^{\mathrm{ef}}$ & $0.01^{\mathrm{g}}$ & $0.08^{\mathrm{a}}$ & $0.09^{\mathrm{a}}$ & $0.08^{\mathrm{b}}$ & $0.00^{\mathrm{h}}$ \\
\hline Adipic acid & $0.05^{\mathrm{g}}$ & $0.14^{\mathrm{d}}$ & $0.18^{\mathrm{c}}$ & $0.05^{\mathrm{g}}$ & $0.00^{\mathrm{k}}$ & $0.04^{\mathrm{h}}$ & $0.01^{\mathrm{j}}$ & $0.00^{\mathrm{k}}$ & $0.10^{\mathrm{e}}$ & $0.33^{\mathrm{a}}$ & $0.26^{\mathrm{b}}$ & $0.06^{\mathrm{f}}$ \\
\hline Total organic acids & $1.70^{\mathrm{f}}$ & $1.93^{\mathrm{d}}$ & $2.18^{\mathrm{c}}$ & $1.45^{\mathrm{g}}$ & $1.07^{\mathrm{j}}$ & $1.76^{\mathrm{e}}$ & $1.23^{\mathrm{h}}$ & $2.24^{\mathrm{b}}$ & $2.25^{\mathrm{b}}$ & $2.79^{\mathrm{a}}$ & $2.78^{\mathrm{a}}$ & $1.95^{\mathrm{d}}$ \\
\hline
\end{tabular}

The sugar and organic acid contents (g/100 g FW) in 12 carrot varieties

Significant at $p \leq 0.05$

*Values (mean of three replications) followed by the same letter within the same column were not significantly different $(p \leq 0.05)$ according to Duncan's test

highest glucose levels were detected in NWC $(4.1 \mathrm{~g} / 100 \mathrm{~g}$ FW) and MiPC (3.8 g/100 $\mathrm{g} \mathrm{FW})$, and the highest sucrose contents were found in NPC $(9.7 \mathrm{~g} / 100 \mathrm{~g} \mathrm{FW})$ and MiWC (7.5 g/100 $\mathrm{g} \mathrm{FW).} \mathrm{Besides,} \mathrm{sucrose} \mathrm{is} \mathrm{the} \mathrm{principal} \mathrm{storage}$ sugar and the level increases with maturity [58]. According to Alasalvar et al. [26], sucrose is the main sugar of purple carrot and is followed by lower contents of fructose and glucose. Similar results were also observed in the present study. Mini- and normal-sized carrot samples had the highest sugar contents, while white carrot samples of each size were rich in sugars. Sugar accumulation during the maturation of carrot varieties is related to the flavours of carrots [56, 59], and total sugar contents of carrot, turnip, and radish roots increase with high $\mathrm{CO}_{2}$. Thus, this feature is important in terms of climate change.

Organic acids are significant compounds of plants for biological pathways as well as human well-being, because organic acids support moderate antibacterial activities [60]. Eight organic acids, namely oxalic, maleic, citric, isocitric, malic, lactic, fumaric, and adipic acids, were observed in the coloured carrot varieties. Among these organic acids, only oxalic, isocitric, malic, and fumaric acids were observed in all carrot varieties. Additionally, Bryant and Overell [61] identified malic, fumaric, and isocitric acids in carrot roots, as well. The present study showed that micro-sized carrots and purple samples were rich in organic acid contents. Thus, flavour compounds, sugars, organic acids, and $\mathrm{pH}$ are the factors that determine the specific aromas of carrot varieties. Moreover, organic acid composition changes with climate, growth conditions, and varieties [62].

\section{Nutritional and chemical components of carrot varieties}

Table 2 presents the basic chemical compositions of the 12 carrot varieties. The carrot root samples significantly differed in their chemical compositions $(p \leq 0.05)$.

Mean dry matter contents of the carrots ranged from 10.9 to $16.4 \%$. Dry matter contents were the highest in NPC (16.4\%) and NOC (15.1\%), followed by MiWC (14.8\%), MWC (14.7\%), and MPC (14.4\%). Gajewski et al. [63] studied different carrot varieties as well and confirmed the highest content of dry matter in purple carrots. Nevertheless, MiWC and MWC showed higher dry matter content than NWC. Thus, normal-sized white carrot holds more water than micro- and mini-white carrot samples.

In the present study, titratable acidity (TA) was determined as well. TA values ranged from 0.2 to $0.40 \mathrm{~g} / 100 \mathrm{~g}$ FW. The highest TA was observed in MYC $(0.4 \mathrm{~g} / 100 \mathrm{~g}$ FW) and MPC (0.4 g/100 g FW), while the lowest results were observed for MiWC (0.2 g/100 g FW) and MiOC $(0.2 \mathrm{~g} / 100 \mathrm{~g} \mathrm{FW})$ samples. In terms of size and colour features of carrots, the micro-sized and purple-coloured carrot roots showed higher TA values. Moreover, TA influences flavour features of food products, and this parameter determines the $\mathrm{pH}$ and durability of carrot products. Therefore, high TA values in micro carrots make them much attractive for sensory characteristics and the food industry.

TA affects the $\mathrm{pH}$ of raw materials. The coloured carrot samples showed high $\mathrm{pH}$ values $(>5.3)$. Similar results were also noted in the literature [63]. In the present study, the $\mathrm{pH}$ 
Table 2 Chemical results of carrot varieties

\begin{tabular}{lllcll}
\hline Type of carrot & Dry matter & Ash & Pectin & TA & pH \\
\hline NOC & $15.06 \pm 0.34^{\mathrm{b}}$ & $0.78 \pm 0.00^{\mathrm{hi}}$ & $1585.00 \pm 0.18^{\mathrm{c}}$ & $0.27 \pm 0.01^{\mathrm{f}}$ & $5.79 \pm 0.04^{\mathrm{bcd}}$ \\
NYC & $11.81 \pm 0.07^{\mathrm{de}}$ & $1.17 \pm 0.04^{\mathrm{b}}$ & $1080.00 \pm 0.01^{\mathrm{e}}$ & $0.25 \pm 0.01^{\mathrm{g}}$ & $5.54 \pm 0.01^{\mathrm{f}}$ \\
NPC & $16.39 \pm 0.09^{\mathrm{a}}$ & $1.42 \pm 0.03^{\mathrm{a}}$ & $935.00 \pm 0.0^{\mathrm{ef}}$ & $0.35 \pm 0.01^{\mathrm{c}}$ & $5.35 \pm 0.02^{\mathrm{h}}$ \\
NWC & $10.92 \pm 0.14^{\mathrm{f}}$ & $1.07 \pm 0.01^{\mathrm{c}}$ & $995.00 \pm 0.06^{\mathrm{ef}}$ & $0.24 \pm 0.0^{\mathrm{gh}}$ & $5.42 \pm 0.0^{\mathrm{gh}}$ \\
MiOC & $11.14 \pm 0.72^{\mathrm{ef}}$ & $0.74 \pm 0.06^{\mathrm{i}}$ & $0.00 \pm 0.00^{\mathrm{g}}$ & $0.23 \pm 0.0^{\mathrm{hi}}$ & $5.82 \pm 0.0^{\mathrm{bc}}$ \\
MiYC & $12.27 \pm 0.25^{\mathrm{d}}$ & $0.82 \pm 0.06^{\mathrm{gh}}$ & $830.00 \pm 0.00^{\mathrm{f}}$ & $0.27 \pm 0.00^{\mathrm{f}}$ & $5.48 \pm 0.0^{\mathrm{fg}}$ \\
MiPC & $12.39 \pm 0.24^{\mathrm{d}}$ & $0.99 \pm 0.05^{\mathrm{d}}$ & $140.00 \pm 0.00^{\mathrm{g}}$ & $0.25 \pm 0.00^{\mathrm{g}}$ & $5.69 \pm 0.00^{\mathrm{e}}$ \\
MiWC & $14.82 \pm 0.14^{\mathrm{b}}$ & $1.12 \pm 0.02^{\mathrm{bc}}$ & $1310.00 \pm 0.10^{\mathrm{d}}$ & $0.22 \pm 0.01^{\mathrm{i}}$ & $6.04 \pm 0.08^{\mathrm{a}}$ \\
MOC & $13.33 \pm 0.46^{\mathrm{c}}$ & $0.87 \pm 0.01^{\mathrm{fg}}$ & $1900.00 \pm 0.00^{\mathrm{b}}$ & $0.31 \pm 0.00^{\mathrm{d}}$ & $5.83 \pm 0.00^{\mathrm{b}}$ \\
MYC & $13.27 \pm 0.40^{\mathrm{c}}$ & $0.90 \pm 0.00^{\mathrm{ef}}$ & $2190.00 \pm 0.00^{\mathrm{a}}$ & $0.40 \pm 0.00^{\mathrm{a}}$ & $5.99 \pm 0.00^{\mathrm{a}}$ \\
MPC & $14.42 \pm 0.59^{\mathrm{b}}$ & $0.95 \pm 0.00^{\mathrm{de}}$ & $1430.00 \pm 0.00^{\mathrm{cd}}$ & $0.38 \pm 0.00^{\mathrm{b}}$ & $5.75 \pm 0.0^{\mathrm{cde}}$ \\
MWC & $14.68 \pm 0.04^{\mathrm{b}}$ & $0.80 \pm 0.00^{\mathrm{ghi}}$ & $1380.00 \pm 0.23^{\mathrm{d}}$ & $0.29 \pm .0 .00^{\mathrm{e}}$ & $5.74 \pm 0.05^{\mathrm{de}}$ \\
\hline
\end{tabular}

Dry matter [\%]; ash [\%]; pectin (mg/100 g FW)

$T A$ titratable acidity (g malic acid/100 g FW)

${ }^{\dagger}$ Significant at $p \leq 0.05$

${ }^{\ddagger}$ Values (mean of three replications) followed by the same letter within the same column were not significantly different $(p \leq 0.05)$ according to Duncan's test values of the carrots ranged from 5.4 to 6.0. The highest $\mathrm{pH}$ values were observed in MiWC (6.0), MYC (6.0), MOC (5.8), and MiOC (5.8). Moreover, the orange samples of different sizes showed much higher $\mathrm{pH}$ values (MOC: 5.8, MiOC: 5.8 and NOC: 5.8). According to Podsedek [64], the differences between samples are due to differences in varieties, soil $\mathrm{pH}$, climate, growth, and storage conditions.

Pectins are subgroups of carbohydrates, provide functionalities to plant cell walls, and protect them against pathogens $[65,66]$. However, enzymes in the human body cannot digest pectins, and gut bacteria help to reduce pectins which are important to prevent colon-related diseases [67]. In the present study, pectin levels ranged from 0 to $2190 \mathrm{mg} / 100 \mathrm{~g} \mathrm{FM}$ in carrot samples. The highest content of pectin was seen in MYC (2190 mg/100 g FM) and MOC (1900 mg/100 g FM). In turn, MiOC showed no presence of pectin, and MiPC had a low amount of pectin content (140 mg/100 g FM). In the study, micro- and normal-carrot samples showed a high amount of pectins (from 1380 to $2190 \mathrm{mg} / 100 \mathrm{~g} \mathrm{FM}$ and from 935 to $1585 \mathrm{mg} / 100 \mathrm{~g} \mathrm{FM}$, respectively); however, pectin contents were the lowest levels (from 0 to $1310 \mathrm{mg} / 100 \mathrm{~g}$ FM) in mini-carrot samples. According to Müller-Maatsch et al. [68], total pectin is divided into chelating agent soluble solids (CASS) and dilute alkaline soluble solids (DASS), and parsley has $47 \mathrm{mg} / \mathrm{g}$ of CASS. Besides, pectins of carrot, cabbage, and onion are sodium-carbonate soluble [69], and the solubility of pectin can alter with postharvest conditions of fruit and vegetables [70]. However, maturation is the main period of plants rising their water-soluble pectin content [71], because pectin fractions may eliminate reactive oxygen species (ROS) which are (non) free radicals of oxygen [72].
The other parameters analyzed in the study were minerals. They are essential for healthy body functions, and plants are good sources of minerals. Table 3 shows the contents of minerals in different varieties of carrots with significant differences. In the present study, it was observed that NYC and NOC were rich in Na; NPC and MYC showed the highest content of K; Ca was abundant in NWC and NYC; Fe was rich in MYC and MPC; and finally, the highest content of $\mathrm{Mg}$ was observed in MiYC and MYC. Normal-sized carrot samples showed higher mineral contents than micro- and mini-sized carrots; moreover, yellow carrots exhibited better results for mineral contents than carrots of other colours for each size. According to Nicolle et al. [41], $\mathrm{K}$ is the most abundant element in carrots, and a similar result was also observed in the present study. Additionally, obvious differences were noted when mineral values were compared with the ash contents of the carrots. NPC and NYC had the highest ash contents, while the lowest results were observed for MiOC and NOC. Thus, normal-sized carrots showed the highest results for ash content, and purple carrots exhibited the highest results for ash content in each size.

\section{Antioxidant activity in carrot varieties}

Table 4 presents the anti-oxidant activities of the 12 carrot varieties. Significant differences in anti-oxidant activities $(p \leq 0.05)$ were observed in the carrot varieties.

Antioxidants inhibit reactive oxygen species that trigger the development of cancers, cardiovascular disorders, aging-related disorders, and other diseases [72]. Therefore, the anti-oxidant properties of plants make them a common food material for use in the food industry. Carrot is rich in 
Table 3 Minerals of carrot varieties

\begin{tabular}{llllll}
\hline Type of carrot & $\begin{array}{l}\text { Macroelements } \\
\text { Na }\end{array}$ & $\begin{array}{l}\text { Macroelements } \\
\text { K }\end{array}$ & $\begin{array}{l}\text { Macroelements } \\
\text { Ca }\end{array}$ & $\begin{array}{l}\text { Macroelements } \\
\text { Mg }\end{array}$ & $\begin{array}{l}\text { Microelements } \\
\text { Fe }\end{array}$ \\
\hline NOC & $378.0^{* \mathrm{~b}}$ & $1773^{\mathrm{j}}$ & $23.3^{\mathrm{d}}$ & $24.4^{\mathrm{h}}$ & $1.5^{\mathrm{l}}$ \\
$\mathrm{NYC}$ & $494.0^{\mathrm{a}}$ & $1954^{\mathrm{c}}$ & $32.7^{\mathrm{b}}$ & $11.7^{\mathrm{k}}$ & $1.9^{\mathrm{k}}$ \\
NPC & $95.9^{\mathrm{k}}$ & $2400^{\mathrm{a}}$ & $27.3^{\mathrm{c}}$ & $3.8^{\mathrm{m}}$ & $2.2^{\mathrm{j}}$ \\
NWC & $372.0^{\mathrm{c}}$ & $1718^{\mathrm{l}}$ & $37.6^{\mathrm{a}}$ & $61.4^{\mathrm{e}}$ & $2.3^{\mathrm{h}}$ \\
MiOC & $102.0^{\mathrm{j}}$ & $1479^{\mathrm{m}}$ & $22.2^{\mathrm{e}}$ & $37.9^{\mathrm{g}}$ & $2.7^{\mathrm{f}}$ \\
MiYC & $355.0^{\mathrm{d}}$ & $1805^{\mathrm{g}}$ & $17.6^{\mathrm{l}}$ & $79.9^{\mathrm{a}}$ & $3.1^{\mathrm{e}}$ \\
MiPC & $274.0^{\mathrm{f}}$ & $1745^{\mathrm{k}}$ & $20.3^{\mathrm{j}}$ & $40.5^{\mathrm{f}}$ & $5.1^{\mathrm{d}}$ \\
MiWC & $301.0^{\mathrm{e}}$ & $1922^{\mathrm{d}}$ & $18.6^{\mathrm{k}}$ & $72.1^{\mathrm{c}}$ & $2.5^{\mathrm{g}}$ \\
MOC & $136.0^{\mathrm{h}}$ & $1782^{\mathrm{h}}$ & $20.3^{\mathrm{h}}$ & $3.9^{\mathrm{l}}$ & $5.3^{\mathrm{c}}$ \\
MYC & $86.1^{\mathrm{l}}$ & $2007^{\mathrm{b}}$ & $22.0^{\mathrm{f}}$ & $74.0^{\mathrm{b}}$ & $13.4^{\mathrm{a}}$ \\
MPC & $55.8^{\mathrm{m}}$ & $1820^{\mathrm{f}}$ & $20.3^{\mathrm{h}}$ & $14.2^{\mathrm{j}}$ & $12.9^{\mathrm{b}}$ \\
MWC & $169.0^{\mathrm{g}}$ & $1869^{\mathrm{e}}$ & $20.7^{\mathrm{g}}$ & $69.5^{\mathrm{d}}$ & $5.4^{\mathrm{c}}$ \\
\hline
\end{tabular}

Minerals (mg/100 g dm)

Significant at $p \leq 0.05$

*Values (mean of three replications) followed by the same letter within the same column were not significantly different $(p>0.05)$ according to Duncan's test
Table 4 The anti-oxidant activities [mmol TE/100 $\mathrm{g} \mathrm{dm}$ ] of carrot varieties

\begin{tabular}{lllr}
\hline Type of carrot & ABTS & FRAP & \multicolumn{1}{l}{ ORAC } \\
\hline NOC & $0.82 \pm 0.03^{* \mathrm{fg}}$ & $0.71 \pm 0.21^{\mathrm{e}}$ & $3.13 \pm 0.19^{\mathrm{j}}$ \\
NYC & $0.48 \pm 0.01^{\mathrm{g}}$ & $0.28 \pm 0.01^{\mathrm{e}}$ & $2.52 \pm 0.03^{1}$ \\
NPC & $7.38 \pm 0.39^{\mathrm{b}}$ & $4.60 \pm 0.2^{\mathrm{b}}$ & $16.17 \pm 1.03^{\mathrm{b}}$ \\
NWC & $0.46 \pm 0.02^{\mathrm{g}}$ & $0.27 \pm 0.03^{\mathrm{e}}$ & $2.84 \pm 0.12^{\mathrm{k}}$ \\
MiOC & $2.42 \pm 0.08^{\mathrm{d}}$ & $2.66 \pm 0.76^{\mathrm{c}}$ & $4.28 \pm 0.30^{\mathrm{g}}$ \\
MiYC & $0.96 \pm 0.01^{\mathrm{f}}$ & $0.64 \pm 0.02^{\mathrm{e}}$ & $3.86 \pm 0.30^{\mathrm{h}}$ \\
MiPC & $7.93 \pm 0.51^{\mathrm{a}}$ & $5.77 \pm 0.17^{\mathrm{a}}$ & $17.06 \pm 0.84^{\mathrm{a}}$ \\
MiWC & $0.81 \pm 0.04^{\mathrm{fg}}$ & $0.58 \pm 0.04^{\mathrm{e}}$ & $5.09 \pm 0.20^{\mathrm{e}}$ \\
MOC & $1.02 \pm 0.04^{\mathrm{f}}$ & $0.73 \pm 0.02^{\mathrm{e}}$ & $5.93 \pm 1.22^{\mathrm{d}}$ \\
MYC & $2.00 \pm 0.14^{\mathrm{e}}$ & $1.62 \pm 0.07^{\mathrm{d}}$ & $4.92 \pm 0.11^{\mathrm{f}}$ \\
MPC & $3.98 \pm 0.17^{\mathrm{c}}$ & $2.21 \pm 0.63^{\mathrm{c}}$ & $15.42 \pm 1.14^{\mathrm{c}}$ \\
MWC & $1.06 \pm 0.03^{\mathrm{f}}$ & $0.82 \pm 0.06^{\mathrm{e}}$ & $3.42 \pm 0.13^{\mathrm{i}}$ \\
\hline
\end{tabular}

TE Trolox equivalents

Significant at $p \leq 0.05$

*Values (mean of three replications) followed by the same letter within the same column were not significantly different $(p>0.05)$ according to Duncan's test

phytochemicals such as phenolic compounds, carotenoids, and ascorbic acid that are essential as nutritional antioxidants in the human diet [73]. In the present study, in vitro anti-oxidant activity assays of all the carrot samples were quantified by ABTS, FRAP, and ORAC methods. Remarkable differences were observed in carrot varieties depending on colour, size, and/or the applied anti-oxidant activity techniques.

In the ABTS method, activities of carrots ranged from 0.5 to $7.9 \mathrm{mmol} \mathrm{TE} / 100 \mathrm{~g} \mathrm{dm}$. The highest results were observed for MiPC $(7.9 \mathrm{mmol} \mathrm{TE} / 100 \mathrm{~g} \mathrm{dm})>>$ NPC $(7.4 \mathrm{mmol}$ $\mathrm{TE} / 100 \mathrm{~g} \mathrm{dm})>>$ MPC $(4.0 \mathrm{mmol} \mathrm{TE} / 100 \mathrm{~g} \mathrm{dm})$. The lowest results were observed in NWC $(0.5 \mathrm{mmol} \mathrm{TE} / 100 \mathrm{~g} \mathrm{dm})$ and NYC $(0.5 \mathrm{mmol}$ TE/100 g dm). According to Singh et al. [74], the ABTS test showed the highest anti-oxidant activity in purple carrot. A similar result was observed in the present study, as well. Therefore, anti-oxidant activity showed a positive correlation with anthocyanins. Sun et al. [75] reported the same relationship.

In the FRAP test, anti-oxidant activities ranged from 0.3 to $5.8 \mathrm{mmol} \mathrm{TE} / 100 \mathrm{~g} \mathrm{dm}$. The MiPC (5.8 mmol TE/100 g dm) showed the highest results, followed by NPC $(4.6 \mathrm{mmol}$ $\mathrm{TE} / 100 \mathrm{~g} \mathrm{dm})$ and MiOC (2.7 mmol TE/100 g dm). The lowest result was observed for NWC $(0.3 \mathrm{mmol} \mathrm{TE} / 100 \mathrm{~g} \mathrm{dm})$ and NYC (0.3 mmol TE/100 g dm). Hence, mini-sized and purple carrots exhibit the highest anti-oxidant activities by FRAP. Singh et al. [74] also showed the highest results for purple carrot in the FRAP assay.

The ORAC assay also showed similar results. The highest results were again observed for MiPC $(17.1 \mathrm{mmol}$ $\mathrm{TE} / 100 \mathrm{~g} \mathrm{dm})$, followed by NPC (16.2 mmol TE/100 $\mathrm{g} \mathrm{dm})$ and MPC (15.4 mmol TE/100 g dm). Thus, purple carrots showed the highest anti-oxidant activity results in the ORAC assay for each size. The lowest results were observed for NYC (2.5 mmol TE/100 g dm) and NWC (2.8 mmol $\mathrm{TE} / 100 \mathrm{~g} \mathrm{dm}$ ). According to Nicolle et al. [41], the darkcoloured carrot demonstrated the highest anti-oxidant activity, and the white carrot showed the lowest activity in the ORAC assay. Therefore, dark-coloured carrots are rich in anthocyanins and thus exhibit strong anti-oxidant activities.

In the present study, the total carotenoid content did not correlate with the total anti-oxidant activity. Mech-Nowak 
et al. [76] also reported similar results. According to Smeriglio et al. [77], the anti-oxidant activity of purple carrot results from anthocyanins and phenolic acids. Similar results were observed in the present study. Algarra et al. [78] compared the anti-oxidant activities of purple carrot and orange carrot growing in the same region and showed that purple carrot exhibited higher anti-oxidant activities than orange carrot depending on the content of anthocyanins.

\section{Conclusions}

The study evaluates the carrot varieties with different size and colour features for vitamin $\mathrm{C}$ as well as chemical contents (dry matter, ash, pectin, titratable acidity, and $\mathrm{pH}$ ), sugar, organic acids, minerals (sodium, potassium, calcium, iron, and magnesium), and anti-oxidant activities. Besides, total polyphenolics and total tetraterpenoids of colourful carrot varieties were presented. According to study results, carrot samples were rich in fructose, sorbitol, glucose, and sucrose as sugars; citric, isocitric, maleic, malic, lactic, fumaric, oxalic and adipic acids were the organic acid compounds in coloured carrot samples. Moreover, sucrose was the dominant sugar and isocitric acid was the most common organic acid in carrot samples. Purple-coloured carrot samples demonstrated the highest results for total sugar, total organic acid, total polyphenolic contents, and anti-oxidant activities (Mini $>$ Normal $>$ Micro). In turn, the lowest results were observed in normal yellow carrot for total polyphenols, and anti-oxidant activities; besides, the lowest total tetraterpenoids were determined in micro-white carrot. However, normal-white carrot exhibited low anti-oxidant results for all three tests (ABTS, FRAP, and ORAC) and the lowest L-ascorbic acid content as well. The conducted study had shown that purple carrots are particularly interesting roots, they are sweet and colorful (they will arouse sensory interest), and additionally, they are rich in bioactive compounds (pectins, vitamin $\mathrm{C}$, and polyphenolic compounds). Therefore, it is worth considering their use in the food industry, especially in the design of children's products.

Acknowledgements This work was conducted under Grant NCBR LIDER IX [LIDER/25/0102/L-9/17/NCBR/2018]. The publication is the result of the research group "Plants4FOOD". Emel Yusuf is a member of Interdisciplinary International Doctoral School at UPWr, co-financed by the European Social Fund under the Operational Program Knowledge Education Development, under Contract No. POWR.03.05.00-00-Z062/18 of June 4, 2019.

Funding This work was conducted under Grant NCBR LIDER IX [LIDER/25/0102/L-9/17/NCBR/2018].

\section{Declarations}

Conflict of interest The authors declare no conflict of interest.
Compliance with ethics requirements This article does not contain any studies with human or animal subjects.

Open Access This article is licensed under a Creative Commons Attribution 4.0 International License, which permits use, sharing, adaptation, distribution and reproduction in any medium or format, as long as you give appropriate credit to the original author(s) and the source, provide a link to the Creative Commons licence, and indicate if changes were made. The images or other third party material in this article are included in the article's Creative Commons licence, unless indicated otherwise in a credit line to the material. If material is not included in the article's Creative Commons licence and your intended use is not permitted by statutory regulation or exceeds the permitted use, you will need to obtain permission directly from the copyright holder. To view a copy of this licence, visit http://creativecommons.org/licenses/by/4.0/.

\section{References}

1. Sadler MJ, Gibson S, Whelan K, Ha MA, Lovegrove J, Higgs J (2019) Dried fruit and public health - what does the evidence tell us? Int J Food Sci Nutr 70(6):675-687. https://doi.org/10.1080/ 09637486.2019.1568398

2. Hall JN, Moore S, Harper SB, Lynch JW (2009) Global variability in fruit and vegetable consumption. Am J Prev Med 36(5):402409. https://doi.org/10.1016/j.amepre.2009.01.029

3. Pollard J, Kirk SFL, Cade JE (2002) Factors affecting food choice in relation to fruit and vegetable intake: a review. Nutr Res Rev 15(2):373-387. https://doi.org/10.1079/NRR200244

4. Lozano R, Naghavi M, Foreman K, Lim S, Shibuya K, Aboyans V, Abraham J, Adair T, Aggarwal R, Ahn SY, AlMazroa MA, Alvarado M, Anderson HR, Anderson LM, Andrews KG, Atkinson C, Baddour LM, Barker-Collo S, Bartels DH, Murray CJL (2012) Global and regional mortality from 235 causes of death for 20 age groups in 1990 and 2010: a systematic analysis for the Global Burden of Disease Study 2010. Lancet 380(9859):2095-2128. https:// doi.org/10.1016/S0140-6736(12)61728-0

5. Nemet D, Barzilay-Teeni N, Eliakim A (2008) Treatment of childhood obesity in obese families. J Pediatr Endocrinol Metab 21(5):461-467. https://doi.org/10.1515/JPEM.2008.21.5.461

6. Clark HR, Goyder E, Bissell P, Blank L, Peters J (2007) How do parents' child-feeding behaviours influence child weight? Implications for childhood obesity policy. J Public Health 29(2):132-141. https://doi.org/10.1093/pubmed/fdm012

7. Wardle J, Carnell S, Cooke L (2005) Parental control over feeding and children's fruit and vegetable intake: how are they related? J Am Diet Assoc 105(2):227-232. https://doi.org/10.1016/j.jada. 2004.11.006

8. Minich DM (2019) A review of the science of colorful, plantbased food and practical strategies for "eating the rainbow." J Nutr Metab. https://doi.org/10.1155/2019/2125070

9. Hammershøj M, Kidmose U, Steenfeldt S (2010) Deposition of carotenoids in egg yolk by short-term supplement of coloured carrot ( Daucus carota) varieties as forage material for egg-laying hens. J Sci Food Agric 90(7):1163-1171. https://doi.org/10.1002/ jsfa.3937

10. Goldman IL, Breitbach DN (1996) Inheritance of a recessive character controlling reduced carotenoid pigmentation in carrot (Daucus carota L.). J Hered 87(5):380-382. https://doi.org/10. 1093/oxfordjournals.jhered.a023018

11. Shao P, Zhang H, Niu B, Jin W (2018) Physical stabilities of taro starch nanoparticles stabilized Pickering emulsions and the potential application of encapsulated tea polyphenols. Int J Biol Macromol 118:2032-2039. https://doi.org/10.1016/j.ijbiomac. 2018.07.076 
12. Akhtar S, Rauf A, Imran M, Qamar M, Riaz M, Mubarak MS (2017) Black carrot (Daucus carota L.), dietary and health promoting perspectives of its polyphenols: a review. Trends Food Sci Technol 66:36-47. https://doi.org/10.1016/j.tifs.2017.05.004

13. Klein CS, Rodriguez-Concepcion M (2015) Carotenoids in carrot. In: Chunxian C (ed) Pigments in fruits and vegetables 217-228. Springer, New York

14. Ravindran R, Swamy MK, Jaganathan R (2019) Therapeutic potential of plant polyphenolics and their mechanistic action against various diseases. Nat Bioact Compd Chem Pharmacol Health Care Pract 2:313-351. https://doi.org/10.1007/978-98113-7205-6_14

15. Afify AE, Romeilah RR, Osfor MMH, Elbahnasawy ASM (2013) Evaluation of carrot pomace (Daucus carota L.) as hypocholesterolemic and hypolipidemic agent on Albino rats. Not Sci Biol 5(1):7-14

16. Hager TJ, Howard LR (2006) Processing effects on carrot phytonutrients. HortScience 41(1):74-79

17. Yusuf E, Wojdyło A, Oszmianski J, Nowicka P (2021) Nutritional, Phytochemical Characteristics and in vitro effect on $\alpha$-Amylase, $\alpha$-glucosidase, lipase, and cholinesterase activities of 12 coloured carrot varieties. Foods 10(4):808. https://doi.org/10.3390/foods 10040808

18. Szczepanek M, Wilczewski E, Pobereżny J, Wszelaczyńska E, Keutgen A, Ochmian I (2015) Effect of biostimulants and storage on the content of macroelements in storage roots of carrot. J Elem 20(4):1021-1031. https://doi.org/10.5601/jelem.2015.20.1.768

19. Olszyk DM, Shiroyama T, Novak JM, Cantrell KB, Sigua G, Watts DW, Johnson MG (2020) Biochar affects essential nutrients of carrot taproots and lettuce leaves. HortScience 55(2):261-271

20. Ergun M, Süslüoğlu Z (2018) Evaluating carrot as a functional food. Middle East J Sci 4(2):113-119

21. MedlinePlus. (2019) Definitions of Health Terms: Minerals. https://medlineplus.gov/definitions/mineralsdefinitions.html

22. Handelman GJ (2001) The evolving role of carotenoids in human biochemistry. Nutrition 17(10):818-822. https://doi.org/10.1016/ s0899-9007(01)00640-2

23. Luby CH, Maeda HA, Goldman IL (2014) Genetic and phenological variation of tocochromanol (Vitamin E) content in wild (Daucus carota L. var. carota) and domesticated carrot (D. carota L. var. sativa). Hortic Res 1(1):15. https://doi.org/10.1038/hortr es. 2014.15

24. Naidu KA (2003) Vitamin C in human health and disease is still a mystery? An overview. Nutr J 2(1):1-10. https://doi.org/10.1186/ 1475-2891-2-7

25. Hsieh CW, Ko WC (2008) Effect of high-voltage electrostatic field on quality of carrot juice during refrigeration. LWT Food Sci Technol 41(10):1752-1757. https://doi.org/10.1016/j.1wt.2008.01. 009

26. Alasalvar C, Grigor JM, Zhang D, Quantick PC, Shahidi F (2001) Comparison of volatiles, phenolics, sugars, anti-oxidant vitamins, and sensory quality of different colored carrot varieties. J Agric Food Chem 49(3):1410-1416. https://doi.org/10.1021/jf000595h

27. Sistrunk WA, Bradley GA, Smittle D (1967) Influence of preharvest factors on carbohydrates in carrots. Proc Am Soc Hortic Sci 90:239-251

28. Que F, Hou XL, Wang GL, Xu ZS, Tan GF, Li T, Wang YH, Khadr A, Xiong AS (2019) Advances in research on the carrot, an important root vegetable in the Apiaceae family. Hortic Res 6(1):1-15. https://doi.org/10.1038/s41438-019-0150-6

29. Gidado A, Daja A, Kasim Z, Audu MM, Idris A (2018) Free glucose, fructose, sucrose and total fructan contents of some commonly consumed vegetables in Maiduguri Metropolis, North East Nigeria. 80. www.iiste.org

30. Robles A, Fabjanowicz M, Chmiel T, Płotka-Wasylka J (2019) Determination and identification of organic acids in wine samples problems and challenges. Trends Anal Chem 120:115630. https:// doi.org/10.1016/j.trac.2019.115630

31. Pijanowski E, Mrożewski S, Horubała A, Jarczyk A (1973) Technologia Produktów Owocowych i Warzywnych, 3rd edn. PWRiL, Poland

32. Wojdyło A, Nowicka P, Bąbelewski P (2018) Phenolic and carotenoid profile of new goji cultivars and their anti-hyperglycemic, anti-aging and anti-oxidant properties. J Funct Foods 48:632-642. https://doi.org/10.1016/j.jff.2018.07.061

33. Wojdyło A, Nowicka P, Laskowski P, Oszmiański J (2014) Evaluation of sour cherry (Prunus cerasus L.) fruits for their polyphenol content, anti-oxidant properties, and nutritional components. J Agric Food Chem 62(51):12332-12345. https:// doi.org/10.1021/jf504023z

34. Wojdyło A, Nowicka P, Tkacz K, Turkiewicz IP (2020) Sprouts vs. microgreens as novel functional foods: variation of nutritional and phytochemical profiles and their in vitro bioactive properties. Molecules 25(20):1-19. https://doi.org/10.1021/ jf504023z

35. Kolniak-Ostek J (2016) Content of bioactive compounds and anti-oxidant capacity in skin tissues of pear. J Funct Foods 23:40-51. https://doi.org/10.1016/j.jff.2016.02.022

36. Ou B, Huang D, Hampsch-Woodill M, Flanagan JA, Deemer EK (2002) Analysis of anti-oxidant activities of common vegetables employing oxygen radical absorbance capacity (ORAC) and ferric reducing anti-oxidant power (FRAP) assays: a comparative study. J Agric Food Chem 50(11):3122-3128. https://doi.org/ $10.1021 / \mathrm{jf} 0116606$

37. Re R, Pellegrini N, Proteggente A, Pannala A, Yang M, RiceEvans C (1999) Antioxidant activity applying an improved ABTS radical cation decolorization assay. Free Radic Biol Med 26(9-10):1231-1237. https://doi.org/10.1016/s0891-5849(98) 00315-3

38. Benzie IFF, Strain JJ (1996) The ferric reducing ability of plasma (FRAP) as a measure of "anti-oxidant power": the FRAP assay. Anal Biochem 239(1):70-76. https://doi.org/10.1006/abio.1996. 0292

39. Davey MW, Van MM, Inz D, Sanmartin M, Kanellis A, Smirnoff N, Benzie IJ, Strain JJ, Favell D, Fletcher J (2000) Plant L-ascorbic acid: chemistry, function, metabolism, bioavailability and effects of processing. J Sci Food Agric 80(7):825-860. https:// doi.org/10.1002/(sici)1097-0010(20000515)80:73.0.co;2-6

40. Granger M, Eck P (2018) Dietary vitamin C in human health. Adv Food Nutr Res 83:281-310. https://doi.org/10.1016/bs.afnr.2017. 11.006

41. Nicolle C, Simon G, Rock E, Amouroux P, Rémésy C (2004) Genetic variability influences carotenoid, vitamin, phenolic, and mineral content in white, yellow, purple, orange, and dark-orange carrot cultivars. J Am Soc Hortic Sci 129(4):523-529

42. Matejkova J, Petrikova K (2010) Variation in content of carotenoids and vitamin $\mathrm{C}$ in carrots. Not Sci Biol 2(4):88-91

43. Ahmad T, Cawood M, Iqbal Q, Ariño A, Batool A, Sabir Tariq RM, Azam M, Akhtar S (2019) Phytochemicals in daucus carota and their health benefits-review article. Foods 8(9):1-22. https:// doi.org/10.3390/foods8090424

44. Kaur C, Kapoor HC (2002) Anti-oxidant activity and total phenolic content of some Asian vegetables. Int J Food Sci Technol 37(2):153-161. https://doi.org/10.1046/j.1365-2621.2002.00552.x

45. Lin JY, Tang CY (2007) Determination of total phenolic and flavonoid contents in selected fruits and vegetables, as well as their stimulatory effects on mouse splenocyte proliferation. Food Chem 101(1):140-147. https://doi.org/10.1016/j.foodchem.2006.01.014

46. Boulekbache-Makhlouf L, Slimani S, Madani K (2013) Total phenolic content, anti-oxidant and antibacterial activities of fruits of Eucalyptus globulus cultivated in Algeria. Ind Crop Prod 41:8589. https://doi.org/10.1016/j.indcrop.2012.04.019 
47. Babbar N, Oberoi HS, Uppal DS, Patil RT (2011) Total phenolic content and anti-oxidant capacity of extracts obtained from six important fruit residues. Food Res Int 44(1):391-396. https://doi. org/10.1016/j.foodres.2010.10.001

48. Côté J, Caillet S, Doyon G, Sylvain JF, Lacroix M (2010) Bioactive compounds in cranberries and their biological properties. Crit Rev Food Sci Nutr 50(7):666-679. https://doi.org/10.1080/10408 390903044107

49. Kamtekar S, Keer V, Patil V (2014) Estimation of phenolic content, flavonoid content, anti-oxidant and alpha amylase inhibitory activity of marketed polyherbal formulation. J Appl Pharm Sci 4(9):61-65. https://doi.org/10.7324/JAPS.2014.40911

50. Manach C, Scalbert A, Morand C, Rémésy C, Jiménez L (2004) Polyphenols: food sources and bioavailability. Am J Clin Nutr 79(5):727-747. https://doi.org/10.1093/ajen/79.5.727

51. Milani A, Basirnejad M, Shahbazi S, Bolhassani A (2017) Carotenoids: biochemistry, pharmacology and treatment. Br J Pharmacol 174(11):1290-1324. https://doi.org/10.1111/bph.13625

52. Delgado-Pelayo R, Gallardo-Guerrero L, Hornero-Méndez D (2014) Chlorophyll and carotenoid pigments in the peel and flesh of commercial apple fruit varieties. Food Res Int 65:272-281. https://doi.org/10.1016/j.foodres.2014.03.025

53. Ellong EN, Billard C, Adenet S, Rochefort K (2015) Polyphenols, carotenoids, vitamin $\mathrm{C}$ content in tropical fruits and vegetables and impact of processing methods. Food Nutr Sci. https://doi.org/ $10.4236 /$ fns. 2015.63030

54. Kidmose U, Hansen SL, Christensen LP, Edelenbos M, Larsen E, Nørbaek R (2006) Effects of genotype, root size, storage, and processing on bioactive compounds in organically grown carrots (Daucus carota L.). J Food Sci 69(9):388-394. https://doi.org/10. 1111/j.1365-2621.2004.tb09955.x

55. Saini RK, Nile SH, Park SW (2015) Carotenoids from fruits and vegetables: Chemistry, analysis, occurrence, bioavailability and biological activities. Rev Food Res Int 76(3):735-750. https://doi. org/10.1016/j.foodres.2015.07.047

56. Wei X, Liu F, Chen C, Ma F, Li M (2014) The Malus domestica sugar transporter gene family: identifications based on genome and expression profiling related to the accumulation of fruit sugars. Front Plant Sci 5:569. https://doi.org/10.3389/fpls.2014.00569

57. Zhao J, Xu Y, Ding Q, Huang X, Zhang Y, Zou Z, Li M, Cui L, Zhang J (2016) Association mapping of main tomato fruit sugars and organic acids. Front Plant Sci 7:1286. https://doi.org/10.3389/ fpls.2016.01286

58. Suojala T (2000) Variation in sugar content and composition of carrot storage roots at harvest and during storage. Sci Hortic 85(1-2):1-19. https://doi.org/10.1016/S0304-4238(99)00133-8

59. Cavagnaro PF (2019) Genetics and genomics of carrot sugars and polyacetylenes. Springer, Cham, pp 295-315

60. Adamczak A, Ożarowski M, Karpiński TM (2019) Antibacterial activity of some flavonoids and organic acids widely distributed plants. J Clin Med. https://doi.org/10.3390/jcm9010109

61. Bryant F, Overell BT (1953) Quantitative chromatographic analysis of organic acids in plant tissue extracts. Biochem Biophys Acta 10(C):471-476. https://doi.org/10.1016/0006-3002(53)90279-0

62. Poyrazoğlu E, Gökmen V, Artık N (2002) Organic acids and phenolic compounds in pomegranates (Punica granatum L.) grown in Turkey. J Food Compos Anal 15(5):567-575. https://doi.org/ 10.1006/jfca.2002.1071

63. Gajewski M, Szymczak P, Dabrowska A, Kret A, Elkner K, Danilcenko H (2007) Some aspects of nutritive and biological value of carrot cultivars with orange, yellow and purple-coloured roots. Veg Crops Res Bull 67:149-161. https://doi.org/10.2478/ v10032-007-0039-z

64. Podsedek A (2007) Natural antioxidants and anti-oxidant capacity of Brassica vegetables: a review. LWT - Food Sci Technol 40(1):1-11. https://doi.org/10.1016/j.lwt.2005.07.023
65. Liu N, Sun Y, Pei Y, Zhang X, Wang P, Li X, Li F, Hou Y (2018) A pectin methylesterase inhibitor enhances resistance to verticillium wilt. Plant Physiol 176(3):2202-2220. https://doi.org/10. 1104/pp.17.01399

66. Morris GA, de Al Torre JG, Ortega A, Castile J, Smith A, Harding SE (2008) Molecular flexibility of citrus pectins by combined sedimentation and viscosity analysis. Food Hydrocoll 22(8):14351442. https://doi.org/10.1016/j.foodhyd.2007.09.005

67. Fukunaga T, Sasaki M, Araki Y, Okamoto T, Yasuoka T, Tsujikawa T, Fujiyama Y, Bamba T (2003) Effects of the soluble fibre pectin on intestinal cell proliferation, fecal short chain fatty acid production and microbial population. Digestion 67(1-2):42-49. https://doi.org/10.1159/000069705

68. Müller-Maatsch J, Bencivenni M, Caligiani A, Tedeschi T, Bruggeman G, Bosch M, Petrusan J, Van Droogenbroeck B, Elst K, Sforza S (2016) Pectin content and composition from different food waste streams. Food Chem 201:37-45. https://doi.org/10. 1016/j.foodchem.2016.01.012

69. Smirnov VV, Golovchenko VV, Vityazev FV, Patova OA, Selivanov NY, Selivanova OG, Popov SV (2017) The anti-oxidant properties of pectin fractions isolated from vegetables using a simulated gastric fluid. J Chem 2017:10. https://doi.org/10.1155/ 2017/5898594

70. Sila DN, Van Buggenhout S, Duvetter T, Fraeye I, De Roeck A, Van Loey A, Hendrickx M (2009) Pectins in processed fruits and vegetables: part ii-structure-function relationships. Compr Rev Food Sci F 8(2):86-104

71. Redgwell R, MacRae E, Hallert I, Fischer P, Perry J, Harker R (1997) In vivo and in vitro swelling of cell walls during fruit ripening. Planta 203:162-173. https://doi.org/10.1007/s004250050 178

72. Sengul M, Yildiz H, Ercisli S, Yildirim E, Turan M, Ozdemir OSD (2011) Some phytochemical characteristics of turnip (Brassica rapa var. rapa L.) roots. Ital J Food Sci 23(3):338-343

73. Gil MI, Tomás-Barberán FA, Hess-Pierce B, Kader AA (2002) Antioxidant capacities, phenolic compounds, carotenoids, and vitamin $\mathrm{C}$ contents of nectarine, peach, and plum cultivars from California. J Agric Food Chem 50(17):4976-4982. https://doi.org/ 10.1021/jf020136b

74. Singh BK, Koley TK, Maurya A, Singh PM, Singh B (2018) Phytochemical and antioxidative potential of orange, red, yellow, rainbow and black coloured tropical carrots (Daucus carota subsp. sativus Schubl. \& Martens). Physiol Mol Biol Plants 24(5):899907. https://doi.org/10.1007/s12298-018-0574-8

75. Sun T, Simon PW, Tanumihardjo SA (2009) Antioxidant phytochemicals and anti-oxidant capacity of biofortified carrots (Daucus carota L.) of various colors. J Agric Food Chem 57(10):41424147. https://doi.org/10.1021/jf9001044

76. Mech-Nowak A, Świderski A, Kruczek M, Łuczak I, KosteckaGugała A (2012) Content of carotenoids in roots of seventeen cultivars of Daucus carota L. ACTA Biochim Pol 59(1):139-141

77. Smeriglio A, Denaro M, Barreca D, D’Angelo V, Germanò MP, Trombetta D (2018) Polyphenolic profile and biological activities of black carrot crude extract (Daucus carota L. ssp. sativus var. atrorubens Alef.). Fitoterapia 124:49-57. https://doi.org/10. 1016/j.fitote.2017.10.006

78. Algarra M, Fernandes A, Mateus N, de Freitas V, Esteves da Silva JCG, Casado J (2014) Anthocyanin profile and anti-oxidant capacity of black carrots (Daucus carota L. ssp. sativus var. atrorubens Alef.) from Cuevas Bajas, Spain. J Food Compos Anal 33(1):7176. https://doi.org/10.1016/j.jfca.2013.11.005

Publisher's Note Springer Nature remains neutral with regard to jurisdictional claims in published maps and institutional affiliations. 